\title{
Institutional Trajectories and Structural Change: the BNDES case
}

\author{
Victo José da Silva Neto'; ; Maria Beatriz Machado Bonacelli ${ }^{1}$
}

Resumo: este artigo discute a coevolução entre instituições e estrutura de produção e inovação setorial. $O$ trabalho se baseia na literatura de economia evolucionária, institucionalista e de sistemas de inovação, em especial sistemas setoriais de inovação. $\mathrm{O}$ primeiro ponto tem enfoque mais geral, no qual as instituições são apresentadas como um dos quatro drivers de transformação de um sistema setorial e recebem feedback do sistema para sua própria evolução. Em seguida, este mecanismo é contextualizado para países desenvolvidos e países em desenvolvimento (sistemas completos/sistemas incompletos de inovação). Finalmente, a atuação do Banco Nacional de Desenvolvimento Econômico e Social - BNDES - é observada em dois momentos. Investiga-se se o banco, como instituição financeira fundamental no sistema nacional de inovação no Brasil, tem direcionado sua seleção setorial rumo a uma maior diversificação setorial/institucional ou se tem priorizado setores tradicionais.

Palavras-chave: instituições; sistema de inovação; mudança estrutural; sistema setorial de inovação; BNDES

\begin{abstract}
: this article discuss the coevolution between institutions and the productive/innovative sectoral structure. The study is based upon the literature of evolutionary economy, institutionalism and innovation systems, specially sectoral systems of innovation. The first point is a general approach in which institutions are presented as one of the four dynamic drivers of sectoral systems transformation and recipient of feedback from the system for it's own evolution. This mechanism is then contextualized for developed and developing countries (complete/incomplete systems of innovation). Finally, the activities of the Banco Nacional de Desenvolvimento Econômico e Social - BNDES - are observed in two moments. It is investigated whether the bank, as a fundamental financial institution in the national innovation system in Brazil, has directed its sectorial selection towards greater sectoral / institutional diversification or has prioritized traditional sectors
\end{abstract}

Keywords: institutions; innovation systems; structural change; sectoral system of innovation; BNDES

Área ABEIN: 5.4 Mudanças técnicas, organizações e instituições

JEL: 039

\footnotetext{
1 Departamento de Política Científica e Tecnológica, Instituto de Geociências, Universidade

Estadual de Campinas
} 


\section{Institutional Trajectories and Structural Change: the BNDES case}

"Innovation driven economic growth needs to be understood as involving the co-evolution of physical and social technologies, and that the dynamics of institutional change should be seen in this light" (NELSON, 2008:4).

\section{Introduction}

The argument supporting this paper is that, in the overall context of production and innovation, economic advisors might follow two paths: doing things in a different way or doing things in the same - but improved (more efficient) - way. The other term for this binarial choice is structural change. An economy based in the extraction and exportation of minerals (e.g.), can undertake the first path, when it chooses to internalize different production and innovation sectors or sub-sectors or deeply transform an already established sector, usually changing the sector knowledge base or finding new types of demand. Or it can ammeliorate the efficiency, the profit margins and the rate of innovation of the already established mineral sector. Usually, countries are involved in both attempts at the same time. However, it is interesting to observe how some institutions tend to follow one trail more than the other.

In this paper we shall discuss, narrowing down the themes:

- How institutions and the sectoral structure - specifically the sectoral innovation structure - interact and how this leads to structural change;

- How the pattern of interaction is well defined in complete innovation systems (in developed countries), and how it is more diffuse in developing countries;

- A possible, very simple, model of two trajectories of interaction between institutions and the sectoral innovation structure for developing countries;

- Some specifities of the financial structure in Brazil - represented by BNDES - and how it's strategic choices act as selection mechanisms upon the type of sectoral composition and the possibilities of institutional diversification

Countries concerned with structural change display the "ability to transform the sectoral composition of the economy and expand into sectors with an increased economic and innovative weight" (MONTOBBIO, 2004:64). This "weight" depends on some production and innnovative sectoral features such as the knoledge base, the technological intensity of sectors, their sources of innovation, labor productivity, employment and value added. Some countries move their sectoral composition toward sectors that are expanding globally and are able to benefit from that; others get stuck with the same sectors based in inferior knowledge bases or losing ground in global demand (MALERBA, 2004; MONTOBBIO, 2004).

Addressing this issue, Malerba (2004:43) states that "the pace of structural change within countries" is guided by "specific and cumulative national trajectories (characterized to some extent by institutional and technological irreversibilities), by the sectoral world market share dynamics and by the sectoral composition of demand". Since the global movements can not be predicted or planned, working with the institutional framework surges as the most promising mechanism to promote sectoral diversification and, eventually, structural change. 
That is why the chosen path - targeting a given rate of structural change - will require different institutional set-ups ${ }^{1}$. In this paper we argue that institutional design is of utter importance to the development of production and innovation systems, irrespective of the degree of structural change expected. The interplay between sectors and national institutions in under scrutiny. The reason for this is the presumption that growth and economic development happens, de facto, at the sectoral level (SCHUMPETER, 1939; NELSON, 2008; MOWERY \& ROSEMBERG, 1998; NIOSI, 2010; MALERBA, 2002); but despite this fact, some institutions are national by nature and they affect sectors differently.

As Malerba has shown $(2002 ; 2004 ; 2014)$, national institutions influence the trajectories of sectors in different ways. Malerba and Nelson (2011) qualify this assumption, arguing that not only the national institutions influence sectoral development, but they actually define which sectors will prosper (and eventually catch up internationally) and which sectors will not. Sectoral institutions, in their interaction with national ones, may be improved or constrained. Thereby, not only the production structure, but also the "institutional set-up" plays a major role in the success or failure of sectoral systems of innovation and production (SSIP).

Concerns about structural change are more alive in the developing countries. We depart from Lundvall's remarks concerning the need to focus in different aspects of innovation system theory when applying the concept to developing countries. In such case, it is necessary to focus on system building and system promoting, either because the system(s) of innovation(s) does not exist or because it's incomplete. As a result, emerging properties of the innovation systems usually observed in the developed countries will not spontaneously sprout in their developing counterparts (LUNDVALL, 2002). Therefore, the institutional design at the national level shapes much of the production and innovation structure of sectors. The absence of coordinated institutional design might impair structural change or even reinforce deeply rooted and traditional routines, raising antistrucutral change institutional set-ups (NIOSI, 2010).

The logic underlying this process is simple. Returning to the example above, inasmuch as institutions foster the improvement of the mineral sector, the economic agents profiting with that economic activity will detain greater economic power which will create incentives for the improvement of those institutions. In other words, there is a self-reinforcing mechanism, that evolutionary economy scholars call coevolution (NELSON, 1994; NELSON 2008; MALERBA, 2002). Even though it is a simple logic, catching the empirical manifestations of this coevolutionary mechanism is much more difficult. Figure 1 ilustrates the basic logic of the institution-sector-institution interaction along with the other elements that provide movement to the sectoral structure, thereby fostering structural change.

\footnotetext{
1 "In general, we find it useful to think about innovation systems in two dimensions. One refers to the structure of the system - what is produced in the system and what competences are most developed? The second refers to the institutional set-up - how does production, innovation and learning take place?", Lundvall et. al, 2002, pp.220.
} 


\section{Figure 1 - Four Drivers of Sectoral Dynamics and Their Coevolutionary Mechanisms}

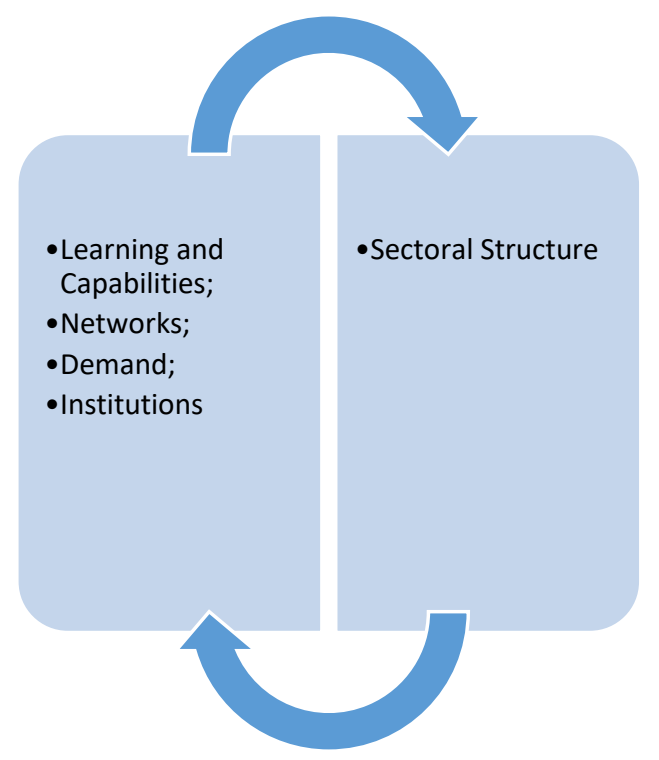

Source: adapted from Malerba \& Adams (2014)

As structural change must be a public concern, the institutional set up is the sphere par excellence of public intervention. As stressed by Niosi (2010:20):

"Many economic systems have trapped themselves in inferior, lowefficiency situations of economic equilibrium. The goal of institutional economics is to discover the sets of institutions, organizations, and policies that have helped (or may in the future help) them to break the vicious dynamics of underdevelopment."

Still, designing institutions is not an easy task. Scholars do not even agree if it's possible to appropriately design this social constructs. Nelson (2008), when proposing the idea of social technology and underlying support institutions, faces the problem of design feasibility. He points to the fact that many social technologies are selfinstitutionalized. This autonomous nature of the institutional set-up is driven by three elements: the repetition of routines and habits that time finally consacrates as an institution, the existence of a complex web of institutions that are interdependent (so changing one of then is complicated) and finally the risk associated with institutional change: a risk that can be greater than that of pioneering physical technologies. Still, this description adequately describes difficulties for institutional design in developed countries. As some scholars argue, the institutional dynamic in developing countries faces its own obstacles (Arocena \& Sutz, 2002; Srnivas \& Sutz, 2008).

Lundvall (2002) points to the power aspects of institution design, a dimension usually neglected. The design of new institutions imply that new incentives and desincentives are being introduced in the economy, inducing agents behaviour towards certain directions. Sometimes, new directions imply competence destruction rather than competence enhancement (Niosi, 2010; Lundvall, 2002). The unequal distribution of power amongst sectors and interest groups in an economy may influence the sort of institutional lock-in preventing new institutional set-up to be created. This problem, argues Lundvall (2002), is probably more pressing in the developing countries, where political systems have minor chances of mitigating the inequality of power distribution. 
Untangling the institutional and sectoral knot is a task that must be accomplished, both by developed and developing countries, with careful considerations of the prevalent national institutions. Altough this is a shared concern, developing countries governments ought to recognize that they are embbeded in a different innovation environment and the interplay between their institutions and the productive/innovative system is sui generis ${ }^{2}$. It is then even more important to study institutions and "their evolution or inertia thorugh time" (NIOSI, 2010:21).

This paper is structured in three sections following this introduction. In the first section the theoretical base of the interplay between national institutions and sectoral systems of innovation and production is presented. The second section brings a brief institutional analysis. The third section aims at the qualification and categorization of the observed patterns of institutional design. A brief discussion of the results and the future research agenda is assessed in the last section.

\section{The Interplay of National Institutions and Sectoral Development}

Malerba \& Adams (2014:193) sums up the argument that sustains this investigation:

"[...] the interaction between national institutions and sectoral systems is not only unidirectional, going from national institutions to sectoral variables. Sometimes, the direction is reversed, such that developments in specific sectors work to influence national institutions."

First, we need to specify what we are considering as "institution".

We shall base our analysis in the categories proposed by Coriat \& Weinstein (2004). They differ institutions in two broad branches, (i) those that provide rules and (ii) those that provide resources. Their definition of institutions in market economies is "the set of social constructs constituted of organizations and systems of rules designed to provide agents with the intangible resources as well as some of the basic tangible resources required to coordinate their actions." (CORIAT \& WEINSTEIN, 2004:331).

Following their interpretation, three groups of institutions are important for the innovation system: (i) intelectual property regimes, the (ii) financial system and the (iii) human resource formation and management (education and labor laws). The authors identify then that two main sets of institutional arrangement are commom: the three axes assume related configurations and shape national innovation systems more or less compatible with certain types of sectors. This combination of different institutions is called "institutional complementarities" (CORIAT \& WEINSTEIN, 2004:339).

The first configuration rises from the combination of a strong IP regime, capital markets and a flexible labor market. This institutional complementarity is the POE (patent/outsider/external) model. Patent stands for the strong appropriability regime, which is the outcome of strong IP laws. The outsider feature concerns the governance pattern of firms: presenting a developed capital market, firms respond to outside standards and controls; finally, external is related to the possibility of absorbtion of knowledge from skilled personel that is outside the firms due to the flexible labor market. The second ideal type of institutional set-up is the OII (open knowledge/insider/internal) model,

\footnotetext{
${ }^{2}$ According to Malerba (2004:27) "institutions may emerge either as a result of deliberate planned decisions by firms or other organizations, or as the unpredicted consequence of agents' interaction”. In developing countries, emergent institutions will hardly display any features required for structural change. The deliberate planning of institutions in this environment consequently gains in importance.
} 
characterized by open knowledge of the public funded basic research, enterprises managed by the inside personel (given that the finance system is predominantly a banking system) and internal construction of human resources and capability accumulation. According to the authors, "a given NSI may at the same time be at the origin of some specific relative institutional advantages for some sectors and activities and of some relative institutional disadvantages for others" (CORIAT \& WEINSTEIN, 2004:340).

As a result, these ideal models would facilitate the development of different economic sectors. The POE model would foster new sectors such as biotechnology and some sub-sectors of telecommunications, marked by the need of highly specialized human resources that usually are outside the firm, relying in the IPR to protect their appropriability margins; the OII model would provide a better environment for scaleintensive and equipment suppliers sectors that would exhibit incremental innovation pattern based in the accumulation of capabilities by the firms permanent workforce, relying in industrial secrets and tacit knowledge to protect their appropriability margins (recovering Pavitt's (1984) taxonomy) (CORIAT \& WEINSTEIN, 2004).

Casper \& Soskice (2004) argue that those two ideal models of NSI are "varieties of capitalism" and that the sectors that fit into each of the two models are those based on radical innovation and those based in incremental innovation. Their interpretation of the interplay between national and sectoral institutions is thus very similar to that of Coriat \& Weinstein (2004). The varieties of capitalism framework defines two archetypes: Liberal Market Economies (LME) and Coordinated Market Economies (CME). The LME suits better radical innovation sectors, while CME is adequate to incremental innovation sectors.

There are two interesting remarks concerning this rigid institutional set-up: even when it seems that an "intruder" sector - let's say, a sector based in radical innovation establishing in a CME - managed to grow and develop in the inadequate national institutional environment, a fine grained analysis will show that it was probably a subsector with compatible characteristics that succeeded. The biotechnology sector based in Germany is the example of this "fake intruder": the actual subsector that developed in German shows much more CME features than LME features; the second remark exemplify a "true invader": the telecommunication sector growth in Sweden. Originally a sector based on radical innovation, one should expect it's failure in an CME environment. Despite that, and thanks to the creation of a cooperative business ecosystem of innovation centered around Ericsson, the sector prospered. Anyway, the authors succeed in pointing the rigid national institutional set up that spurs some sectors while ditching others (CASPER \& SOSKICE, 2004).

The kind of interplay between national institutional set-ups and sectors (and the sectoral institutions) is totally centered in the history of developed countries. The institutional choices - or, in a more deterministic way, the sectoral choices - presented by the studies above mentioned are all made within a broad environment marked by abundance of resources. As a result, there is not much preocupation regarding structural change. Similar choices must be made in the South, but in a different atmosphere of innovation, or as Srinivas and Sutz (2008) put it, in a different innovation environment.

The innovation environment in the South is embbeded in scarcity. This scarcity is manifold: it regards inputs, human resources and even institutions. Therefore, the logic driving innovation activities in the South is different. Sometimes innovation happens because of scarcity. Differently of Srnivas and Sutz (2008) though, we do not want to 
work with this new cateogory of innovation, but it is useful to expose how structural change is a sine qua non condition to any innovation policy formulation, including institutional design.

Considering that developing economies suffer from the lack of institutions, it should not surprise us to observe that the interplay between national institutions and sectoral systems of innovation is sui generis. There is not such a strict induction as that discussed by Coriat \& Weinstein (2004) and Casper \& Soskice (2004) nor the "institutional irreversibilities" mentioned by Malerba (2004).

Figure 2 -Institutional trajectories in an environment of abundance

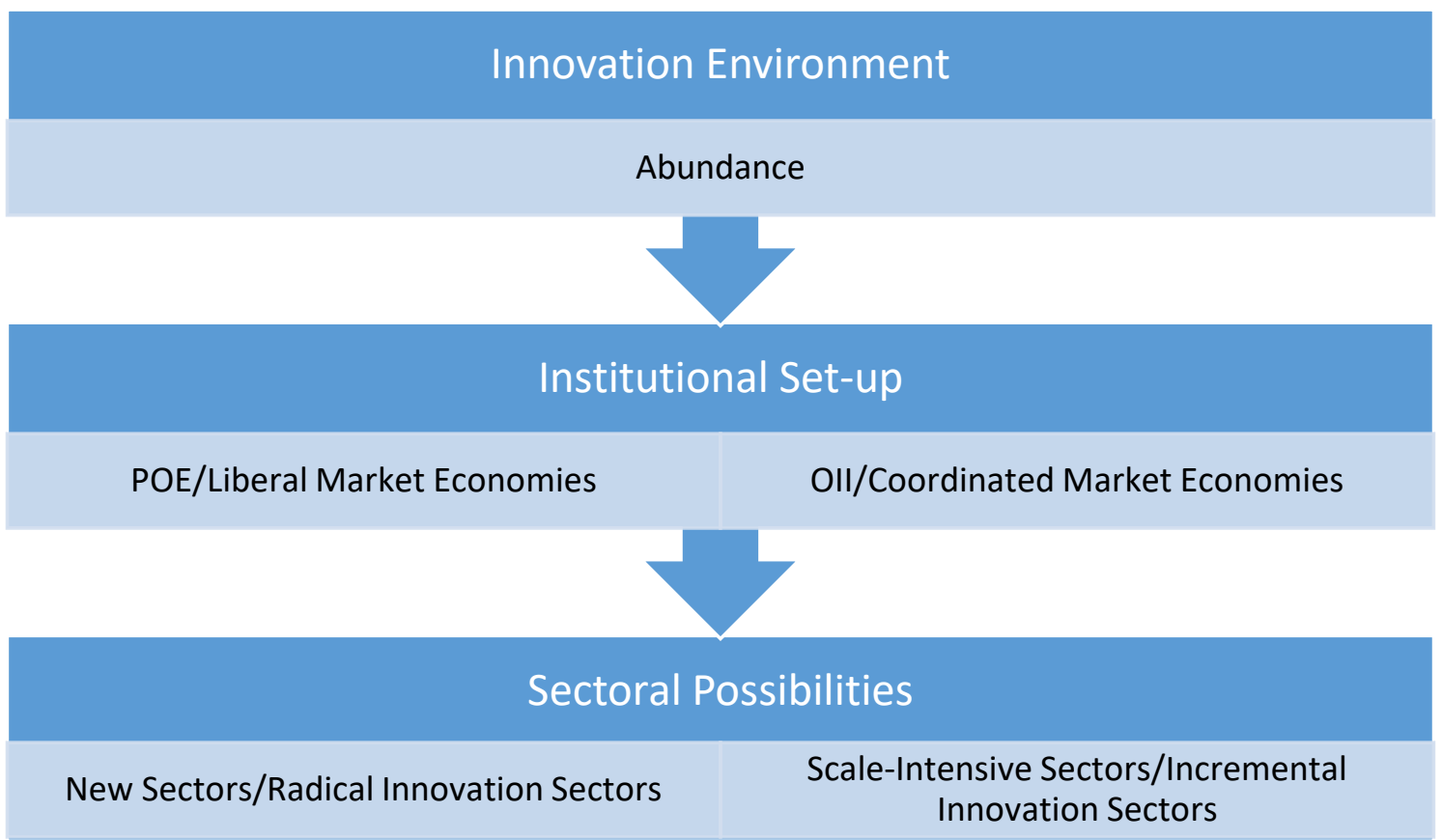

Source: author's elaboration

Altenburg (2009) pinpoints the fragility of institutions in developing countries: uncertainty is more pervasive, laws and rules are less enforceable. There is also a paradox related to the need for state participation, mitigating market failures, and the emergence of government failures once the State enters the scene. In other words, the government is both a source of solutions and problems when an innovation system is under construction and institutions are in the process of consolidation ${ }^{3}$.

In the meantime, sectors have to be selected for the composition of the sectoral systems of innovation and production (SSIPs). Niosi (2010) argues that, with the exception of USA and China (and we could add Brazil, Russia and India, at least), all the other countries should pick a few sectors to specialize in, and channel public resources (sometimes, scarce resources as mentioned) into this well-defined targets. However, the sectoral choice will define future possibilities of technical and economic development. As put by Altenburg (2009:50), “[...] there is a need to support product differentiation

\footnotetext{
${ }^{3}$ This duality of govenrment's role is related to two principal issues: (i) the state is a political entity, thereby it has political interests that may or may not coincide with the maximization of "social output" to use Altenburg's (2009) words. Bureaucracy may conduct the industrial and innovation policy according to some interest groups desires; and (ii) due to it's maturity stage, most developing contries won't display technical competences required to resolve complex market failures. Altenburg, T. (2009), Building Inclusive Innovation Systems in Developing Countries.
} 
and sectoral differentiation since development is path dependent on the opportunities opened up by the capacities generated by previous activities".

What is then the adequate sectoral composition of a developing economy whose innovation system is under construcion? One should expect to find more space to foster different sectors once there is not a constraining institutional set-up. However, the inexistence of constraints is the positive side of an ambivalent phenomenon: the inexistence of a strong institutional set-up leaves no sistematic and coordenated sectoral stimulus coming from the national level.

Figure 3 - Possible institution-sector-institution nexus

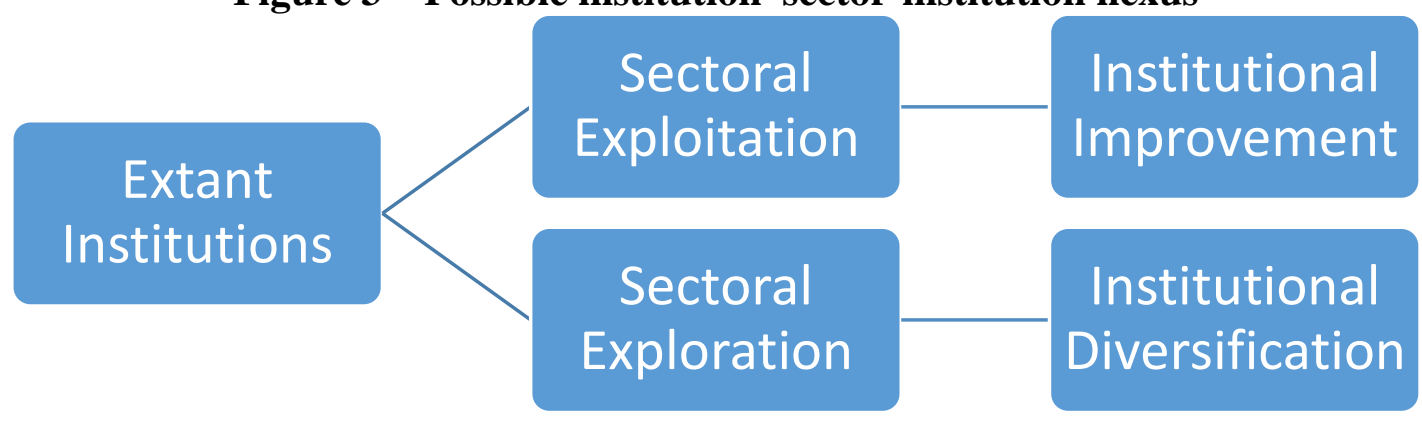

Source: author's elaboration

Thus, it is possible to delineate two different strategies:

(i) Sectoral Exploitation: in this case, the institutional mechanisms will facilitate innovation in stablished sectors. "Facilitate" can be understood as promoting or selecting. It is a safer strategy, as the sector is already consolidated within the economic structure. But because of that, it leaves the productive/innovative structure unchanged; consequently, the odds are that no institutional diversification will be necessary to fullfill the sector's needs. This strategy implies a trajectory of institutional improvement.

(ii) Sectoral Exploration: in this case, the institutional mechanisms will foster new sectors, or the transformation of the knowledge and technological base of an established sector. Again, the institutional mechanism may act as a generator of sectoral diversity or as a selector device. The stakes are higher and so are the risks of this strategy. However, when successful, there is a great chance of the newborn sector demands new, diverse institutions. This strategy implies a trajetory of institutional diversification.

Regarding the first moment, of institution to sector influence, Nelson (2008) gives several exemples of how broad institutional changes (such as the Bayh-Dole Act) in the USA opened space for the emergence of new sectors (such as biotechnology). The same Nelson (2008) points to the need of specific, sectoral institutions once the industry matures, such as specific labor legislation or financial regulation.

Regarding the second moment, of sector to institution influence, an earlier work of Nelson (1994) stated that

"various features of the institutional environment themselves tend to adapt and change in response to pushes and pulls exerted by the development of a new industry. The processes involved here are not market processes, at least not of the standard variety, but involve the 
forming of collective bodies, decisions of voluntary organizations, government agencies, and political action.” (NELSON, 1994:55).

Malerba and Nelson (2011) conclude that sectors whose needs are coherent with the national institutions characteritics have greater chances to flourish in developing countries, and they base their assertion upon diverse case studies. If one takes a picture of the institutional framework and of the sectoral composition, this is certainly true. But as we are trying to pinpoint, the institutional framework itself (co)evolves, and a sector that had no chance of growing up in a given institutional environment may have its chances renewed when diverse institutions are put in place. So, if one consider the institutional framework in construction pari-passu the sectoral composition, agents choices (exemplified by the two trajectories of sectoral/institutional exploitation/exploration), through mutual influence, may disclose new possible horizons.

This mutual influence in flux is what we shall observe for the case of the larger financial institution in Brazil: the sectoral choices of the national development bank Banco Nacional de Desenvolvimento Econômico e Social (BNDES). It exemplify a financial institution working as a non-market selection mechanism, targeting economic development and providing scarce resources to specific sectors. The consequences of the bank's choices in terms of innovation structure and institutional incentives are the subject of the next session.

\section{Structural Change and Institutions in Brazil: BNDES sectoral selection}

From an endless array of possible institutions, the financial aspects of national institutional framework was selected. Finance is commonly listed alongside intelectual property rights, labor regulation and the research system, as one of the most important institutions for the promotion of innovation. There is general agreement that this applies to developed and developing countries. However, in the developed countries, as emphasized by Coriat \& Weinstein (2004) and Casper \& Soskice (2004), the options are "should we foster a capital market financial institutional arrangement or a banking centered one?". In the developing economies, where sistemic scarcities are present and risks are higher, the financial institution choice should be "what elements of the incomplete financial system can state ${ }^{4}$ action mitigate or circumvent?" and "this financial incentives are working as stimulus to which kind of sectoral structure?".

The national development banks are a traditional institutional response to this question. As BNDES is the major financial institution in Brazil fostering development ${ }^{5}$, it is quite reasonable that it's goals are not restricted to changing the sectoral structure of the economy, and the great variety of credit lines is an exemple of this multipurposal institution. Still, the impact in the sectoral composition exists, even though it is not always the first goal of the bank's operations. This is why we have not concentrated our analysis uniquely in the credit lines for innovation. As the innovative and productive structures are deeply entrenched, stimulus for the productive structure do reverberate in the

\footnotetext{
4 " [...] governments play a key role in the system, because only they can dictate or frame some of the relationships among the component organizations, possess enough resources to create missing organizations in the system, and can direct the whole or part of the system towards creation of new sectors." (NIOSI, 2010:21).

${ }^{5}$ There are other important financial institutions such as FINEP, devoted to innovation projects. However, the capital requirements and the personel requirements for structural change can only be found in the BNDES.
} 
innovative sphere. According to Musacchio \& Lazzarini (2015), there are two key features of developing banks: they are public entities and their mission is to solve failures in the credit market, specially those related to investments that require a long term for maturing. The authors also point to the widespread dissemination of development banks. They register 288 development banks worldwide in 2011, mostly concentrated in south and east Asia, Africa and Latin America (MUSACCHIO \& LAZZARINI, 2015:272-3).

We look at the BNDES operation in two moments (2002 and 2014) to assess what kind of sectoral composition the bank privileged. The innovation aspects of the sectoral composition shall be analysed through PINTEC's database. Looking at two different moments, we may visualize eventual changes in the pattern of incentive. Sectoral disbursement is analysed without the desaggregation in different credit lines. This refinement could present some different results concerning specific credit lines, however, as our objective is to highlight the general positioning of the institution, the aggregate numbers are coherent. The two snapshots - 2002 and 2014 - were chosen because

(i) they mark a period of unchanged political leadership in Brazil, so the broad political stance regarding the direction of the economy shows - if not homogeneity - signs of continuity;

(ii) within this period there is no serious domestic crisis in Brazil, considering that the 2007-2008 financial crisis, at least in the short run, did not hit the country as it hit developed economies;

(iii) they comprise a period of economic prosperity in Brazil, when the macroeconomic conditions (international reserves, GDP growth, wages growth, favorable international trade results) for structural change incentives were available

Questions we will try to approach are:

- From one period to the other, loans went to the same set of sectors or to new, emerging sectors?

- In the case of sectoral continuity, does the sector experienced any change in its innovation activities structure from the first to the second period?

Graphic 1 exposes the continuous growth of BNDES total disbursements throughout the period in consideration. In the twelve years under analysis the bank operations grew 4,5 fold, from R \$ 37 billions in 2002 to $\mathrm{R} \$ 187$ billions in 2014 .

Graphic 1 - BNDES total disbursements, 2002 - 2014 (R\$ billions)

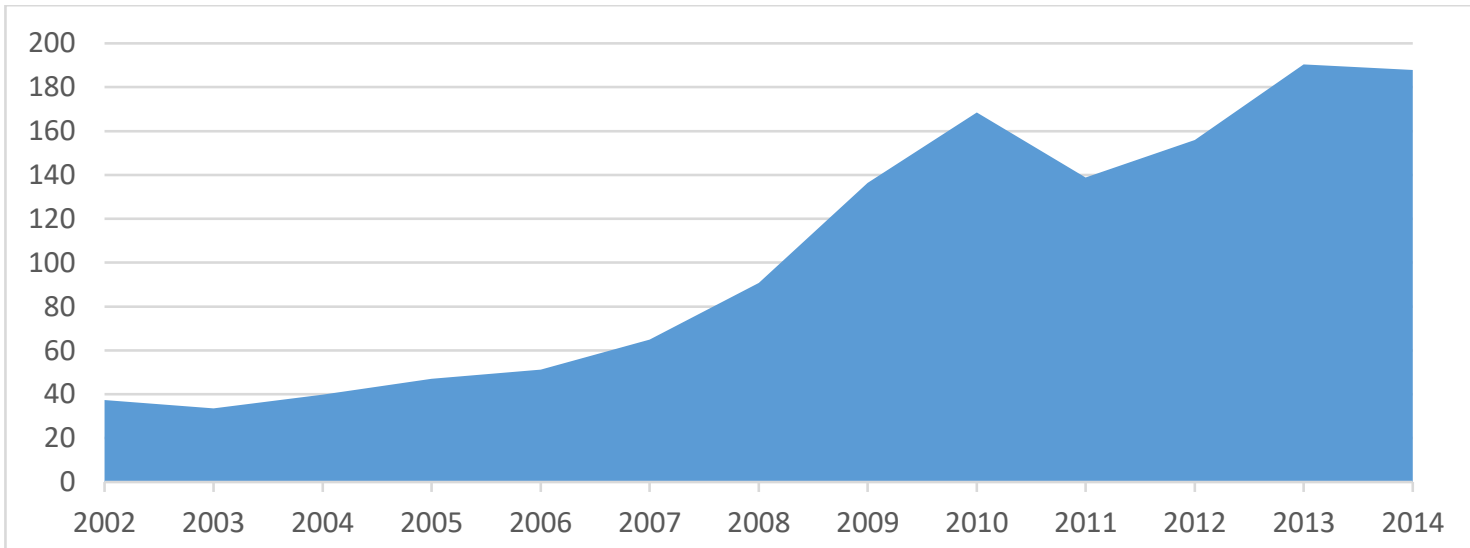

Source: author's elaboration based on BNDES data 


\section{Changes in the Set of Sectors}

The period registers sectoral deconcentration of the banks operations. In 2002, the top fifteen recipient sectors accounted for $88,03 \%$ of total disbursements, in contrast with $83,31 \%$ in 2014 . The composition of the top fifteen recipient sectors also changed. Following $\mathrm{CNAE}^{6}$ categories, BNDES separates sectors in four categories: processing industries, commerce and services, farming and the extractive industry. Given that the top 15 sectors account for more than $83 \%$ of total disbursements in both periods, we shall focus our analysis in this sub-set.

In 2002 the top fifteen recipient sectors were composed by nine sectors of the processing industries, five sectors belong to commerce and services plus the farming sector. In 2014 there is a sweeping shift towards commerce and services, both in the top fifteen recipients and in the overall picture. In the top fifteen, nine sectors come from the commerce and services group, five from the processing industries and again, farming makes the list. Table 1 and graphic 3 show changes in the fifteen biggest recipients and in total disbursement.

In the overall, sectoral composition moved towards commerce and services too. In 2002, 45,85\% of the banks operations went to processing industries sectors. In 2014 this percentage falls to $25,04 \%$. The percentage of operations received by sectors related to commerce and services goes in the opposite direction: from $41,43 \%$ of total operations in 2002 to $64,42 \%$ in 2014. Emphasis given to farming and commerce and services sectors could be justified by sectoral up/downstream links in the economy. Nonetheless, analysis conducted by Silva \& Oliveira (2015) and Guilhoto \& Picerno (1995) have show that upstream and downstream linkages indexes are higher for processing industries sectors. So, even if one considers intersectorial economic thrust, excessive focus in commerce and services sectors comes up as a questionable direction for strategic ${ }^{7}$, low interest loans. Still, it is fearsome to simply state that the shift towards service sectors implies an inferior strategy of development or structural change. As discussed by Fornari et. al (2017), there is no antagonism between industry and the services sectors: the service sectors interact with manufacturing sectors and this intersectoral linkages usually spur economic growth.

Table 1 - Top 15 recipient sectors of BNDES disbursements in two moments

\begin{tabular}{|c|c|c|c|}
\hline \multicolumn{2}{|c|}{2002} & \multicolumn{2}{|c|}{2014} \\
\hline Sector (CNAE) & $\begin{array}{l}\text { Value }(\mathbf{R} \$ \\
\text { millions) }\end{array}$ & Sector (CNAE) & $\begin{array}{c}\text { Value (R\$ } \\
\text { millions) }\end{array}$ \\
\hline Power and gas & 8852 & $\begin{array}{l}\text { Ground } \\
\text { transportation }\end{array}$ & 28118 \\
\hline $\begin{array}{l}\text { Other transportation } \\
\text { equipments }\end{array}$ & 6587 & Power and gas & 19598 \\
\hline Farming & 4509 & Commerce & 17579 \\
\hline $\begin{array}{l}\text { Ground } \\
\text { transportation }\end{array}$ & 2136 & Farming & 16775 \\
\hline Food industry & 2090 & Public administration & 11641 \\
\hline
\end{tabular}

\footnotetext{
${ }^{6}$ CNAE stands for "Classificação Nacional de Atividades Econômicas”, or National Classification of Economic Activities.

${ }^{7}$ As stressed by Altenburg (2009) the subsidies that selected sectors benefit from are necessarily a transfer of scarce resources within any economy. It is expected then, that the selected sectors have strategic importance in the present, generating income and employment, and in the future,
} 


\begin{tabular}{|c|c|c|c|}
\hline $\begin{array}{l}\text { Vehicles and } \\
\text { extensions }\end{array}$ & 1459 & $\begin{array}{l}\text { Auxiliary activities } \\
\text { of transportation and } \\
\text { delivery }\end{array}$ & 10428 \\
\hline Cellulose and paper & 1273 & Construction & 10315 \\
\hline Commerce & 1112 & $\begin{array}{l}\text { Other transportation } \\
\text { equipments }\end{array}$ & 6250 \\
\hline Metallurgy & 1020 & Food industry & 6124 \\
\hline $\begin{array}{l}\text { Machines and } \\
\text { equipments }\end{array}$ & 929 & $\begin{array}{l}\text { Vehicles and } \\
\text { extensions }\end{array}$ & 5296 \\
\hline Chemistry & 877 & Telecommunications & 5295 \\
\hline Construction & 763 & Real-state activities & 5225 \\
\hline Telecommunications & 654 & Coal, oil and fuels & 5198 \\
\hline $\begin{array}{l}\text { Optic, hardware and } \\
\text { electronic equipment }\end{array}$ & 348 & $\begin{array}{l}\text { Insurance and } \\
\text { financial activities }\end{array}$ & 4624 \\
\hline Metal products & 332 & Cellulose and paper & 4019 \\
\hline TOTAL & $32941(88,03 \%)$ & TOTAL & $156485(83,31 \%)$ \\
\hline
\end{tabular}

Source: author's elaboration based on BNDES data

A simple parameter displays the banks priorities: the ratio between sectoral disbursements variation and total disbursements variation serves as a proxy of how important financing a given sector was to BNDES in the period concerned. Data is presented in Table 2 and corroborates the vision that the services were the privileged target of the banks operations in the period. Oil, coal and fuels is the only sector in the procesign industries that displays a priority ratio bigger than 1 (in other words, is the only sector in the processing industry whose sectoral disbursment growth was bigger than total BNDES disbursement growth).

Table 2 - Priority Ratio for Selected Sectors

\begin{tabular}{|c|c|c|c|c|}
\hline \multirow[t]{2}{*}{ Sector/Variable } & Sectora & ment (R\$ & \multirow{2}{*}{$\begin{array}{c}\Delta \text { sectoral } \\
\text { disbursement } \\
(2002-2014)\end{array}$} & \multirow{2}{*}{$\begin{array}{c}\text { Priority Proxy } \\
\text { ( } \Delta \text { sectoral } \\
\text { disbursement/ } \\
\Delta \text { total } \\
\text { disbursement) }\end{array}$} \\
\hline & 2002 & 2014 & & \\
\hline
\end{tabular}

\begin{tabular}{|c|c|c|c|c|}
\hline $\begin{array}{l}\text { Ground } \\
\text { transportation }\end{array}$ & 2136 & 28118 & $1216 \%$ & 3,03 \\
\hline Power and gas & 8852 & 19598 & $121 \%$ & 0,30 \\
\hline Commerce & 1112 & 17579 & $1481 \%$ & 3,68 \\
\hline Farming & 4509 & 16775 & $272 \%$ & 0,68 \\
\hline $\begin{array}{l}\text { Public } \\
\text { adminisration }\end{array}$ & 159 & 11641 & $7221 \%$ & 17,96 \\
\hline $\begin{array}{l}\text { Auxiliary activities } \\
\text { of transportation } \\
\text { and delivery }\end{array}$ & 281 & 10428 & $3611 \%$ & 8,98 \\
\hline Construction & 763 & 10315 & $1252 \%$ & 3,11 \\
\hline $\begin{array}{l}\text { Other } \\
\text { transportation } \\
\text { equipments }\end{array}$ & 6587 & 6250 & $-5 \%$ & $-0,01$ \\
\hline Food industry & 2090 & 6124 & $193 \%$ & 0,48 \\
\hline
\end{tabular}




\begin{tabular}{|c|c|c|c|c|}
\hline $\begin{array}{l}\text { Vehicles and } \\
\text { extensions }\end{array}$ & 1459 & 5296 & $263 \%$ & 0,65 \\
\hline Telecommunication & 654 & 5295 & $710 \%$ & 1,77 \\
\hline Real-state activities & 296 & 5225 & $1665 \%$ & 4,14 \\
\hline Coal, oil and fuel & 183 & 5198 & $2740 \%$ & 6,82 \\
\hline $\begin{array}{l}\text { Insurance and } \\
\text { financial activities }\end{array}$ & 162 & 4624 & $2754 \%$ & 6,85 \\
\hline Cellulose and paper & 1273 & 4019 & $216 \%$ & 0,54 \\
\hline \multicolumn{5}{|c|}{ Sectors out of top 15} \\
\hline Metallurgy & 1020 & 2478 & $143 \%$ & 0,36 \\
\hline $\begin{array}{l}\text { Machines and } \\
\text { Equipment }\end{array}$ & 929 & 2909 & $213 \%$ & 0,53 \\
\hline Chemistry & 877 & 3572 & $307 \%$ & 0,76 \\
\hline $\begin{array}{l}\text { Precision } \\
\text { Instruments }\end{array}$ & 348 & 626 & $80 \%$ & 0,20 \\
\hline Metal Products & 332 & 1588 & $378 \%$ & 0,94 \\
\hline
\end{tabular}

Source: author's elaboration based on BNDES data

The priority ratio of service sectors leaves no space for doubt. BNDES operations expansion was carried out through a specific trajectory: fostering services and commerces, inclusive those delivered by the public administration.

Graphic 2 - Aggregated Compostion of BNDES disbursements, 2002-2014
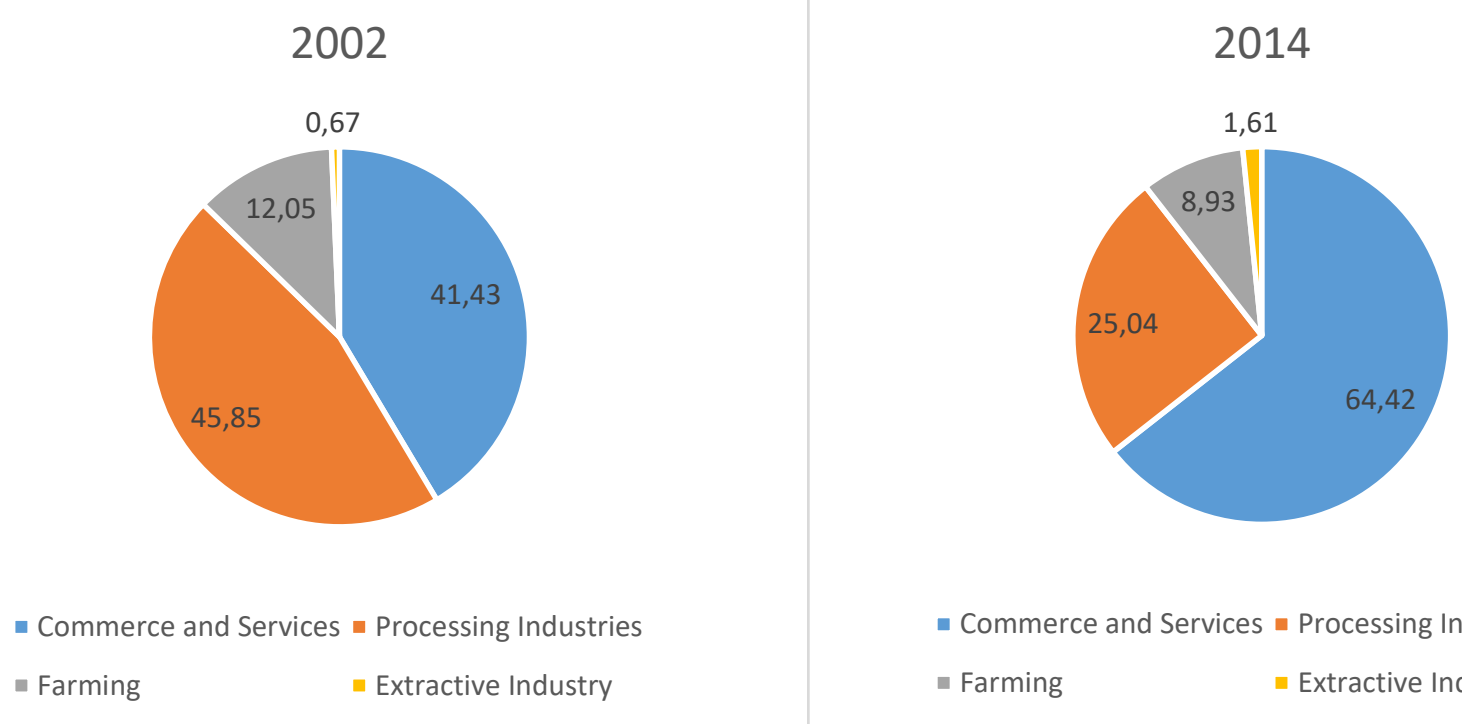

Source: author's elaboration based on BNDES data

More interesting is the evolution of sectoral composition related to innovation patterns. We have crossed the BNDES and PINTEC's database to track the innovation features of the recipient sectors. PINTECs database provides information about the innovation activities for enterprises displayed at the industry level (CNAE). BNDES sectoral data from 2002 was compared to the 2003 version of PINTEC, which accounts for innovation activities in brazilian enterprises within the 2001-2003 period. Similarly, 
BNDES sectoral data of 2014 was compared to PINTEC's 2014 publication, comprising enterprise information from 2012-2014.

From the 15 sectors of the 2002's set, PINTEC (2003) provides information related to 8 (those in the processing industries with the exception of precision instruments which is presented in a different level of disaggregation); from the sample of 2014, PINTEC (2014) provides data related to 8 of the 15 selected sectors: the five sectors in processing industries plus telecommunication, energy and gas and construction services. Therefore, for both periods, intrasectoral data is available for around $50 \%$ of the samples.

\section{Intrasectoral Changes}

PINTEC $(2003,2014)$ database presents all the processing industries sector's data. In the service sectors sub-set, there is data for construction, power and gas and telecommunications sectors. Tables 3, 4, and $\mathbf{5}$ sums up data from this source. All sectors registered increasing net sales revenues that surmount at least $100 \%$. It is noteworhty that the R\&D investment grew in all sectors. However, those that left the top fifteen sectors in BNDES disbursements were those spending the most in R\&D of the sample. The growth average of $R \& D$ investment considering the processing sectors without the four excluded sectors (metallurgy, machines and equipments, chemistry, metal products) is $176 \%$. When they are included, the growth average rises to $239 \%$. This is evidence that the BNDES selection mechanism did not took in consideration fostering sectors where R\&D investment was growing faster.

The result of this selection bias is the diminishing numbers of the ratio between net sales revenues and $\mathrm{R} \& \mathrm{D}$ investment, or $R \& D$ intensity. This means that companies were putting their resources coming from their sales somewhere else then $R \& D$. This decrease is evident in the processing sectors that remained in the top 15 sectors along the period. Other transportation equipments and Vehicles and extensions were the sectors with highest variations $(4,1 \%$ to $2,27 \%$ in the first, $1,56 \%$ to $1,1 \%$ in the second). When the service sectors join the set, the mean goes further below: from 1,32\% in 2002 to $0,73 \%$ in 2014.

Regarding structural change, a few remarks can be made. The priority assigned to service sectors has implications. First, the innovation rate mean $(26 \%)$ is much lower in the service sectors compared to the processing industry sectors (39\%). Despite that, and somewhat surprisingly, the selected service sectors assign a higher importance to R\&D internal activities ( $21 \%$ is the mean of respondents) than processing industry sectors (17\% mean). Still, the R\&D staff/total workforce and the $\$$ R\&D invested/Net Sales Revenue is much lower in the services sectors, which pushed the general mean to lower leves than those of the sample - in the counterfactual world - assuming that no processing industry sector was de-prioritized. 
Table 3 - Innovation rate and net sales revenues for selected sectors, 2002 - 2014

\begin{tabular}{|c|c|c|c|c|c|c|c|c|c|c|}
\hline \multirow[t]{2}{*}{ Sector/Variable } & \multicolumn{2}{|c|}{ Innovation Rate } & \multicolumn{2}{|c|}{$\begin{array}{c}\text { Net Sales } \\
\text { Revenues (R\$ } \\
\text { billions) }\end{array}$} & \multirow[t]{2}{*}{$\begin{array}{l}\Delta \text { Net } \\
\text { Sales } \\
\text { revenues }\end{array}$} & \multicolumn{2}{|c|}{ Value invested in R\&D (R\$ millions) } & \multirow[t]{2}{*}{$\begin{array}{l}\Delta \text { Value } \\
\text { Invested in } \\
\text { R\&D }\end{array}$} & \multicolumn{2}{|c|}{$\begin{array}{c}\text { \$ R\&D } \\
\text { invested/Net } \\
\text { Sales Revenue }\end{array}$} \\
\hline & 2002 & 2014 & 2002 & 2014 & & 2002 & 2014 & & 2002 & 2014 \\
\hline Power and Gas & - & $29 \%$ & - & 205,54 & - & - & 348 & - & - & $0,17 \%$ \\
\hline Construction & - & $27 \%$ & - & 39,37 & - & - & 224 & - & - & $0,57 \%$ \\
\hline Telecommunication & - & $21 \%$ & - & 148,18 & - & - & 503 & - & - & $0,34 \%$ \\
\hline Services Mean & - & $26 \%$ & - & 131,03 & - & - & 358,33 & - & - & $0,27 \%$ \\
\hline $\begin{array}{l}\text { Other Transportation } \\
\text { Equipments }\end{array}$ & $27 \%$ & $38 \%$ & 16,6 & 48,5 & $192 \%$ & 680 & 1100 & $62 \%$ & $4,10 \%$ & $2,27 \%$ \\
\hline Food Industry & $34 \%$ & $45 \%$ & 165,6 & 525 & $217 \%$ & 165 & 776 & $370 \%$ & $0,10 \%$ & $0,15 \%$ \\
\hline Vehices and extensions & $40 \%$ & $39 \%$ & 84,56 & 265,47 & $214 \%$ & 1318 & 2913 & $121 \%$ & $1,56 \%$ & $1,10 \%$ \\
\hline Oil, coal and fuels & $35 \%$ & $42 \%$ & 92,54 & 307,45 & $232 \%$ & 563 & 2665 & $373 \%$ & $0,61 \%$ & $0,87 \%$ \\
\hline Cellulose and paper & $31 \%$ & $30 \%$ & 33,59 & 68,69 & $104 \%$ & 73 & 275 & $277 \%$ & $0,22 \%$ & $0,40 \%$ \\
\hline Processing Industry Mean & $33 \%$ & $39 \%$ & 78,58 & 243,02 & $192 \%$ & 560 & 1546 & $176 \%$ & $1,32 \%$ & $0,96 \%$ \\
\hline All sectors mean & $33 \%$ & $34 \%$ & $\mathbf{7 8 , 5 8}$ & 201,03 & $192 \%$ & 560 & 1101 & $97 \%$ & $1,32 \%$ & $0,73 \%$ \\
\hline \multicolumn{11}{|c|}{ Sectors out of top 15} \\
\hline Metalurgy & $34 \%$ & $38 \%$ & 69,1 & 165,49 & $139 \%$ & 167 & 558 & $234 \%$ & $0,24 \%$ & $0,34 \%$ \\
\hline Machines and Equipment & $44 \%$ & $40 \%$ & 51,07 & 130,41 & $155 \%$ & 363 & 1041 & $187 \%$ & $0,71 \%$ & $0,80 \%$ \\
\hline Chemistry & $42 \%$ & $50 \%$ & 111,83 & 262,67 & $135 \%$ & 496 & 1966 & $296 \%$ & $0,44 \%$ & $0,75 \%$ \\
\hline Metal Products & $33 \%$ & $29 \%$ & 27,05 & 78,78 & $191 \%$ & 63 & 206 & $227 \%$ & $0,23 \%$ & $0,26 \%$ \\
\hline Out of Top 15 mean & $38 \%$ & $39 \%$ & 64,76 & 159,34 & $155 \%$ & 272,25 & 942,75 & $236 \%$ & $0,41 \%$ & $0,54 \%$ \\
\hline $\begin{array}{l}\text { Processing Industry mean } \\
\text { including sectors out of the } \\
\text { top } 15 \text { by } 2014\end{array}$ & $35 \%$ & $39 \%$ & 72,44 & 205,83 & $176 \%$ & 432 & 1278 & $239 \%$ & $0,91 \%$ & $0,77 \%$ \\
\hline
\end{tabular}

Source: author's elaboration based in PINTEC $(2003,2014)$ data. 
Table 4 - Government support for innovation in selected sectors, 2002 - 2014

\begin{tabular}{|c|c|c|c|c|c|c|c|c|c|c|}
\hline \multirow[t]{3}{*}{ Sector/Variable } & \multicolumn{10}{|c|}{ Government Support } \\
\hline & \multicolumn{2}{|c|}{ Fiscal excemption } & \multicolumn{2}{|c|}{ Credit for Machinery Aquisition } & \multicolumn{2}{|c|}{ Credit for R\&D projects } & \multicolumn{2}{|c|}{ Public Procurement } & \multicolumn{2}{|c|}{$\begin{array}{c}\text { Four } \\
\text { categories } \\
\text { total }\end{array}$} \\
\hline & 2002 & 2014 & 2002 & 2014 & 2002 & 2014 & 2002 & 2014 & 2002 & 2014 \\
\hline Power and Gas & - & 39 & - & 15 & - & 46 & - & 9 & - & 109 \\
\hline Construction & - & 14 & - & 336 & - & 19 & - & 164 & - & 533 \\
\hline Telecommunication & - & 42 & - & 115 & - & 57 & - & 52 & - & 266 \\
\hline Services Mean & - & 32 & - & 155 & - & 41 & - & 75 & - & 303 \\
\hline Other Transportation Equipments & 4 & 17 & 11 & 57 & 16 & 15 & - & 5 & 31 & 94 \\
\hline Food Industry & 9 & 235 & 515 & 2512 & 46 & 117 & - & 100 & 570 & 2964 \\
\hline Vehices and extensions & 7 & 119 & 165 & 185 & 14 & 72 & - & 4 & 186 & 380 \\
\hline Oil, coal and fuels & 1 & 2 & 7 & 35 & 2 & 13 & - & 0 & 10 & 50 \\
\hline Cellulose and paper & 4 & 27 & 97 & 358 & 3 & 14 & - & 4 & 104 & 403 \\
\hline Processing Industry Mean & 5 & 80 & 159 & 629 & 16 & 46 & - & 23 & 180 & 778 \\
\hline All sectors mean & 5 & 62 & 159 & 452 & 16 & 44 & - & 42 & 180 & 600 \\
\hline \multicolumn{11}{|c|}{ Sectors out of top 15} \\
\hline Metalurgy & 9 & 34 & 32 & 161 & 23 & 25 & - & 1 & 64 & 221 \\
\hline Machines and Equipment & 15 & 133 & 304 & 669 & 10 & 100 & - & 51 & 329 & 953 \\
\hline Chemistry & 29 & 156 & 120 & 294 & 14 & 94 & - & 23 & 163 & 567 \\
\hline Metal Products & 6 & 70 & 390 & 934 & 2 & 54 & - & 20 & 398 & 1078 \\
\hline Out of Top 15 mean & 15 & 98 & 212 & 515 & 12 & 68 & - & 24 & 239 & 705 \\
\hline $\begin{array}{l}\text { Processing Industry mean } \\
\text { including sectors out of the top } \\
15 \text { by } 2014\end{array}$ & 9 & 88 & 182 & 578 & 14 & 56 & - & 23 & 206 & 746 \\
\hline
\end{tabular}

Source: author's elaboration based in PINTEC $(2003,2014)$ data. 
Table 5 - Human resources and the assigned importance of in-house R\&D in selected sectors, 2002 - 2014

\begin{tabular}{|c|c|c|c|c|c|c|c|c|c|}
\hline \multirow[t]{2}{*}{ Sector/Variable } & \multicolumn{2}{|c|}{$\begin{array}{l}\text { \% of firms considering in-house R\&D } \\
\text { highly important for innovation }\end{array}$} & \multicolumn{2}{|c|}{ R\&D staff } & \multirow[t]{2}{*}{$\begin{array}{l}\Delta R \& D \\
\text { staff }\end{array}$} & \multicolumn{2}{|c|}{ Total workforce } & \multicolumn{2}{|c|}{$\begin{array}{l}\text { R\&D staff/total } \\
\text { workforce }\end{array}$} \\
\hline & 2002 & 2014 & 2002 & 2014 & & 2002 & 2014 & 2002 & 2014 \\
\hline Power and Gas & - & $22,28 \%$ & - & 531 & - & - & 125207 & - & $0,42 \%$ \\
\hline Construction & - & $19,42 \%$ & - & 2910 & - & - & 245175 & - & $1,19 \%$ \\
\hline Telecommunication & - & $21,43 \%$ & - & 2198 & - & - & 170176 & - & $1,29 \%$ \\
\hline Services Mean & - & $21,04 \%$ & - & 1880 & - & - & 180186 & - & $0,97 \%$ \\
\hline Other Transportation Equipments & $25,94 \%$ & $22,00 \%$ & 4031 & 6456 & $60 \%$ & 63780 & 128087 & $6,32 \%$ & $5,04 \%$ \\
\hline Food Industry & $13,35 \%$ & $7,94 \%$ & 1808 & 4039 & $123 \%$ & 943247 & 1631159 & $0,19 \%$ & $0,25 \%$ \\
\hline Vehices and extensions & $32,24 \%$ & $21,01 \%$ & 5053 & 14462 & $186 \%$ & 288624 & 496388 & $1,75 \%$ & $2,91 \%$ \\
\hline Oil, coal and fuels & $22,80 \%$ & $10,52 \%$ & 1486 & 2116 & $42 \%$ & 111177 & 191947 & $1,34 \%$ & $1,10 \%$ \\
\hline Cellulose and paper & $15,27 \%$ & $5,82 \%$ & 586 & 1192 & $103 \%$ & 136301 & 187195 & $0,43 \%$ & $0,64 \%$ \\
\hline Processing Industry Mean & $21,92 \%$ & $13,46 \%$ & 2593 & 5653 & $118 \%$ & 308626 & 526955 & $2,01 \%$ & $1,99 \%$ \\
\hline All sectors mean & $21,92 \%$ & $16,30 \%$ & 2593 & 4238 & $63 \%$ & 308626 & 396917 & $2,01 \%$ & $1,61 \%$ \\
\hline \multicolumn{10}{|c|}{ Sectors out of top 15} \\
\hline Metalurgy & $16,77 \%$ & $12,09 \%$ & 1289 & 1248 & $-3 \%$ & 179373 & 245109 & $0,72 \%$ & $0,51 \%$ \\
\hline Machines and Equipment & $29,58 \%$ & $19,53 \%$ & 4866 & 6247 & $28 \%$ & 352117 & 423340 & $1,38 \%$ & $1,48 \%$ \\
\hline Chemistry & $39,86 \%$ & $43,63 \%$ & 3555 & 10091 & $184 \%$ & 222872 & 313425 & $1,60 \%$ & $3,22 \%$ \\
\hline Metal Products & $14,39 \%$ & $12,16 \%$ & 1213 & 2038 & $68 \%$ & 286494 & 453110 & $0,42 \%$ & $0,45 \%$ \\
\hline Out of Top 15 mean & $25,15 \%$ & $21,85 \%$ & 2731 & 4906 & $69 \%$ & 260214 & 358746 & $1,03 \%$ & $1,41 \%$ \\
\hline $\begin{array}{l}\text { Processing Industry mean including } \\
\text { sectors out of the top } 15 \text { by } 2014\end{array}$ & $23,36 \%$ & $17,19 \%$ & 2654 & 5321 & $88 \%$ & 287109 & 452196 & $1,57 \%$ & $1,73 \%$ \\
\hline
\end{tabular}

Source: author's elaboration based in PINTEC $(2003,2014)$ data. 
More important is fostering sectors that had not received such amount of financial resources before (from BNDES). This new sectors (specially public administration, oil/coal/fuels, real-state services and financial services) are not new in the sense that their productive structure was recently internalized: they are new to the institutional environment in concern. Another way to see this is the radical transformation of this sectors: by means of funding at an unprecedent scale, the innovative dynamics of the sector has changed. This sectors emerge as primary recipients of financial resources and they bring a different type of demand, opening space for a rarely used innovation instrument: public procurement. The important feature of this "new" set of sectors is the institutional diversification they conceal.

The results are not good for structural change if one thinks of the public and private participation. Government support has increased in all the categories, public procurement being one of then. Credit for machinery acquisition became widespread (it is not hard to find sectors where it grew 5 fold). In the opposite direction, the ratio of money invested in $\mathrm{R} \& \mathrm{D} / \mathrm{Net}$ sales revenues diminished in all sectors. The sectors where this ratio increased are those that were de-prioritized. Not only that, but the importance assigned to in-house R\&D fell in all processing industry sectors (present in the top 15) from 2002 to 2014, as graphic 3 illustrates.

\section{Graphic 3-Assigned importance of in-house R\&D for firms in selected sectors, $2002-2014$}

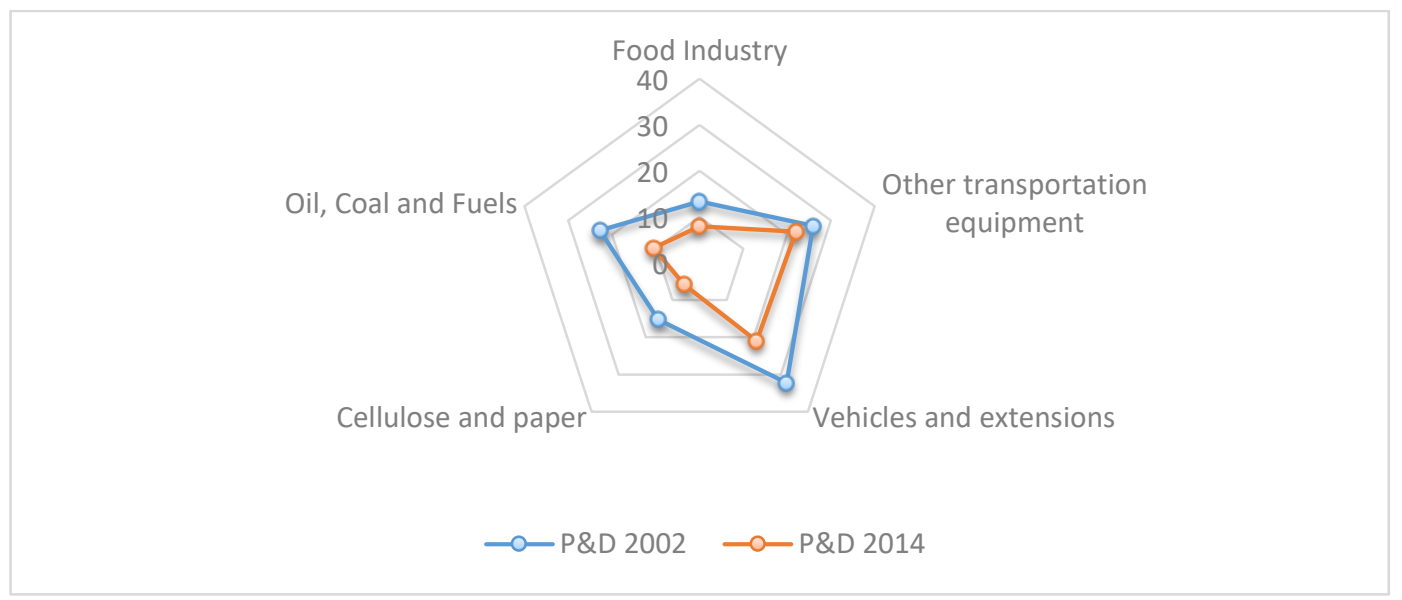

Source: author's elaboration based in PINTEC $(2003,2014)$ data.

This fact makes our sample an exemple of public engagement and private withdrawal. The institutional selection mechanism of BNDES should not point to that direction. Government support must exist and must grow, using new and different instruments, but this has to go hand in hand with the private sector.

\section{Discussion}

First, some general caveats: the analysis conducted does not intend or has the capacity to infer if the BNDES sectoral choices have conditioned the innovative structure of the sectors under scrutiny. In other words, we do not engage in causal links investigation in the present research. With this in view, the authors believe that seeking to elucidate eventual causal links between BNDES sectoral choices (as well as the choices of other institutions) is a natural sequence for this research. Specifically about the BNDES, it is important to disaggregate data by credit lines. This would bring a more complete understanding of the bank's operations and its sectoral choices. BNDES was 
seen as a selector mechanism for sectoral/institutional diversity; it would be interesting to test if it can proceed as a generator of sectoral/institutional diversity.

It is important to find causal links and go beyond: data presents shrinking numbers of in-house R\&D importance for the majority of sectors. Could this decrease in the importance of in-house $R \& D$ be associated with the receipt of financial resources? In other words, is BNDES promoting the crowding out of private resources or fostering a different innovation strategy (supplier dominated/scale-intensive - [PAVITT, 1984])? Another possibilite is that the general economic downturn is affecting this sectors investment capacity (IBGE, 2016) and therefore, the financial aid coming from BNDES is acting as an important countercyclical instrument.

The public procurement contracts are an evidence of institutional diversification. Unfortunately it is not possible, using this database, to compare the numbers between 2002-2014 (PINTEC started to collect this set of data in its latest version). Still, the superior numbers of service sector's related to public procurement ( 3 fold the number of contracts with processing industries) in 2014 leave the following question: was the financial priority given to this sectors that made possible this new mechanism of interaction for innovation?

In the introduction of this paper we proposed that the extant institutions could engage in institutional improvement and/or institutional diversification. The emergence of public procurment is an evidence of the latest, while there is no evidence of the former. In fact, while government support increased in all sectors from 2002 to 2014, the ratio of money invested in R\&D to net sales revenue decreased in the vast majority of sectors. The ratio of personel dedicated to $\mathrm{R} \& \mathrm{D}$ in relation to total workers also decreased. The decrease would have been mitigated if the processing industry sectors remained prioritized, as the difference amongst the calculated means show (top fifteen mean in $2014=1,61 \%$; counterfactual mean $=1,73 \%$ ). This scenario resembles institutional deterioration. If we add to this figure the general decrease of importance assigned to internal $\mathrm{R} \& \mathrm{D}$, there is enough reason to worry about the traditional innovative structure dedicated to $\mathrm{R} \& \mathrm{D}$, as well as its related institutions (such as national laboratories and universities). There is reason to worry because, even though we cannot assert that it is because of BNDES operations that the innovation structure changed towards this deterioration, we can assert that the brazilian development bank is putting huge amounts of resources into this type of sectors. If this resources do not counterbalance the observed trend, but add to it, they could create perverse incentives of the most diverse types to the institutional deterioration - the exact opposite of the trajectorie of institutional improvement we proposed - of traditional R\&D innovation institutions. In other words, the bank's choices act upon the sectoral structure as a selection mechanism. It will, thereby, define the possible institutional paths coupled to this sectoral composition (NELSON, 1994).

Another important remark is the necessity to broaden the scope of this study, to include economic variables such as employment, labor productivity and capital productivity. This is the way to put together the innovation and the production system. If the institutional impact over this two dimensions could be assessed, our understanding regarding the dynamics of industrial evolution would be enhanced. Montobbio (2004) analyses such aspects in his study of structural change; still, the structural change inhis work is not constrained or related to any institution: it happens, but there is no sign of why or induced by whom. 
The ability to encourage institutional diversification through new sectors/sectroal transformation must be developed without abandoning pre-existing institutions. In this case, there is no need to destroy the old to create the new. As put by Nelson (2008) "Human purpose, and human beliefs, play an important role both in the generation of the institutional alternatives on which selection works, and in determining what survives and what does not". For an innovation system in formation, it might be wise to diversificate institutions while avoiding shutting the door on possible institutional trajectories.

\section{References}

ACEMOGLU, D., ROBINSON, J., (2012). Why nations fail: the origins of power, prosperity, and poverty. London: Profile.

AROCENA, R., SUTZ, J., (2002). Innovation Systems and Developing Countries, DRUID working paper nr. 02-05, DRUID Conference Proceedings.

ALTENBURG, T., (2009). Building inclusive innovation systems in developing countries: challenges for IS research, in Lundvall, B. (ed.), Handbook of innovation systems and developing countries : building domestic capabilities in a global setting. Edward Elgar.

BANCO NACIONAL DE DESENVOLVIMENTO ECONÔMICO E SOCIAL. Estatísticas e Desempenho. Último acesso em 20/04/2017. Disponível em: <http://www.bndes.gov.br/wps/portal/site/home/transparencia/estatisticasdesempenho>. Acesso em: 20 abr. 2017.

CASPER, S., SOSKICE, D., (2004). Sectoral systems of innovation and varieties of capitalism: explaining the development of high-technology entrepreneurship in Europe, in Malerba, F. (ed.), Sectoral Systems of Innovation: concepts, issues and analysis of six major sectors in Europe. New York, NY: Cambridge University Press.

CORIAT, B., WEINSTEIN, O., (2004). National institutional frameworks, institutional complementarities and sectoral system of innovation, in Malerba, F. (ed.), Sectoral Systems of Innovation: concepts, issues and analysis of six major sectors in Europe. New York, NY: Cambridge University Press.

FORNARI, V., GOMES, R., HIRATUKA, C., (2017). Mudanças recentes nas relações intersetoriais: um exame das atividades de serviço e industriais, Revista Brasileira de Inovação, 16:1, pp. $157-188$.

GUILHOTO, J., PICERNO, A., (1995). Estrutura produtiva, setores chave e multiplicadores setoriais, Revista Brasileira de Economia, 49:1, pp. 35 - 61.

INSTITUTO BRASILEIRO DE GEOGRAFIA E ESTATÍSTICA (IBGE), (2003). Pesquisa de inovação tecnológica. Rio de Janeiro: IBGE, 2003. Disponível em:< http://www.pintec.ibge.gov.br/index.php?option=com_content\&view=category\&layout $=$ blog $\&$ id $=18 \&$ Itemid=16 > . Acesso em: 20/04/2017.

INSTITUTO BRASILEIRO DE GEOGRAFIA E ESTATÍSTICA (IBGE), (2014). Pesquisa de inovação tecnológica. Rio de Janeiro: IBGE, 2014. Disponível em:< http://www.pintec.ibge.gov.br/index.php?option=com_content\&view=category\&layout =blog\&id=30\&Itemid=46 > . Acesso em: 20/04/2017.

INSTITUTO BRASILEIRO DE GEOGRAFIA E ESTATÍSTICA (IBGE), (2016). Pesquisa de inovação: 2014/IBGE, Coordenação de Indústria - Rio de Janeiro: IBGE. 
LUNDVALL, B.A., JOHNSON, B., ANDERSEN, E., DALUM, B., (2002). National systems of production, innovation and competence building, Research Policy, 31, pp. $213-231$.

MALERBA, F., (2002) Sectoral systems of innovation and production, Research Policy, 31 , pp. $247-264$.

MALERBA, F., (ed.) (2004). Sectoral Systems of Innovation: concepts, issues and analysis of six major sectors in Europe. New York, NY: Cambridge University Press.

MALERBA, F., (2004). Sectoral system of innovation: basic concepts, in Malerba, F. (ed.), Sectoral Systems of Innovation: concepts, issues and analysis of six major sectors in Europe. New York, NY: Cambridge University Press.

MALERBA, F., ADAMS, P., (2014). Sectoral Systems of Innovation, in Dodgson, M., Gann, D., \& Phillips, N., (eds.), The Oxford Handbook of Innovation Management. Oxford, UK: Oxford University Press.

MALERBA, F., NELSON, R., (2011). Learning and catching up in different sectoral systems: evidence from six industries, Industrial and Corporate Change, 20:6, pp. $1645-1675$.

MONTOBBIO, F., (2004). Sectoral dynamics and structural change: stylized facts and "system of innovation" approaches, in Malerba, F. (ed.), Sectoral Systems of Innovation: concepts, issues and analysis of six major sectors in Europe. New York, NY: Cambridge University Press.

MOWERY, D., ROSEMBERG, N., (1998). Paths of innovation: technological change in 20th century America. Cambridge, UK; New York, NY: Cambridge University Press.

MUSSACHIO, A., LAZZARINI, S., (2015). Reinventando o Capitalismo de Estado: o leviatã nos negócios, Brasil e outros países. São Paulo: portfolio Penguin.

NELSON, R., (1994). The co-evolution of technology, industrial structure, and supporting institutions, Industrial and Corporate Change, 3:1, pp. $47-63$.

NELSON, R., (2008). What enables rapid economic progress: what are the needed institutions?, Research Policy, 37, pp. 1 - 11.

NIOSI, J., (2010). Building national and regional innovation systems: institutions for economic development. Cheltenhan, UK: Edward Elgar.

PAVITT, K., (1984). Sectoral patterns of technology change: towards a taxonomy and a theory, Research Policy, 13, pp. 343 - 373.

SCHUMPETER, J. A., (1964 [1939]) Business cycles: a theoretical, historical and statistical analysis of the capitalist process. 5th ed. New York, NY: McGraw-Hill.

SILVA, I., OLIVEIRA, M., (2015). Estrutura produtiva e distribuição de renda no Brasil: uma abordagem insumo-produto, Revista Pesquisa \& Debate, 26:48, pp.169-189.

SRNIVAS, S., SUTZ, J., (2008). Developing countries and innovation: searching for a new analytical approach, Technology in Society, 30:2, pp. $129-140$. 